\title{
Ophthalmic manifestations of ionising radiation among interventionalists
}

\begin{tabular}{|c|c|}
\hline $\begin{array}{l}\text { Authors: } \\
\text { Lumko Ngetu } \\
\text { Wayne Marai } \\
\text { André Rose } \\
\text { William I.D. R }\end{array}$ & $\begin{array}{l}10 \\
10 \\
0 \\
a^{3}(1)\end{array}$ \\
\hline $\begin{array}{l}\text { Affiliations: } \\
{ }^{1} \text { Department } \\
\text { Ophthalmolo } \\
\text { the Free State } \\
\text { South Africa }\end{array}$ & $\begin{array}{l}\text { of } \\
\text { sy, University of } \\
\text { Bloemfontein, }\end{array}$ \\
\hline $\begin{array}{l}{ }^{2} \text { Department } \\
\text { Health, Unive } \\
\text { Free State, BI } \\
\text { South Africa }\end{array}$ & $\begin{array}{l}\text { of Community } \\
\text { rsity of the } \\
\text { oemfontein, }\end{array}$ \\
\hline $\begin{array}{l}{ }^{3} \text { School of Hea } \\
\text { University of } \\
\text { New South W } \\
\text { Australia }\end{array}$ & $\begin{array}{l}\text { alth Sciences, } \\
\text { Sydney, } \\
\text { ales, Sydney, }\end{array}$ \\
\hline $\begin{array}{l}\text { Correspondin } \\
\text { André Rose, } \\
\text { andrerose200 }\end{array}$ & $\begin{array}{l}\text { g author: } \\
\text { 0@yahoo.com }\end{array}$ \\
\hline $\begin{array}{l}\text { Dates: } \\
\text { Received: } 05 \\
\text { Accepted: } 24 \\
\text { Published: } 07\end{array}$ & $\begin{array}{l}\text { Jct. } 2018 \\
\text { July } 2019 \\
\text { Nov. } 2019\end{array}$ \\
\hline $\begin{array}{l}\text { How to cite tr } \\
\text { Ngetu L, Mara } \\
\text { Rae WID. Oph } \\
\text { manifestation } \\
\text { radiation amo } \\
\text { interventiona } \\
\text { Eye Health. 2C } \\
\text { https://doi.or } \\
\text { aveh.v78i1.48 }\end{array}$ & $\begin{array}{l}\text { is article: } \\
\text { is W, Rose A, } \\
\text { thalmic } \\
\text { s of ionising } \\
\text { ng } \\
\text { lists. Afr Vision } \\
19 ; 78(1) \text {, a480. } \\
\text { g/10.4102/ } \\
0\end{array}$ \\
\hline $\begin{array}{l}\text { Copyright: } \\
\text { ( 2019. The } A \\
\text { Licensee: AOS } \\
\text { is licensed unc } \\
\text { Creative Comr } \\
\text { Attribution Lic }\end{array}$ & $\begin{array}{l}\text { uthor(s). } \\
\text { IS. This work } \\
\text { der the } \\
\text { nons } \\
\text { ense. }\end{array}$ \\
\hline Read online: & \\
\hline 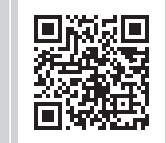 & $\begin{array}{l}\text { Scan this QR } \\
\text { code with your } \\
\text { smart phone or } \\
\text { mobile device } \\
\text { to read online. }\end{array}$ \\
\hline
\end{tabular}

Authors:

Affiliations:

${ }^{1}$ Department of

South Africa

University of Sydney,

New South Wales, Sydney,

Corresponding author:

André Rose,

Accepted: 24 July 2019

How to cite this article:

Ngetu L, Marais W, Rose A

Rae WID. Ophthalmic

radiation among

Afr Vision

https://doi.org/10.4102/

Copyright:

(C) 2019. The Author(s).

Licensee: AOSIS. This work

is licensed under the

Creative Commons
Background: Ionising radiation (IR) is an occupational hazard for interventionalists. Dry eye syndrome may develop. There may be damage to the corneal epithelium, causing irritation and ulceration. Radiation-induced cataracts commonly develop in the posterior sub-capsular (PSC) region of the lens and are more common in the left eye.

Aim: The aim of this study was to describe the ophthalmological findings in South African interventionalists occupationally exposed to IR.

Setting: This study was conducted in South Africa.

Methods: A prospective cross-sectional study was conducted. Interventional radiologists (25), adult cardiologists (42) and paediatric cardiologists (31) were recruited at conferences and included in the study. Convenience sampling was used. Participants completed a survey that collected data on their demographics, their cataract risk factors and co-morbid diseases, their occupational history, their radiation safety practices and their training in occupational history. Participants' eyes were examined using a slit lamp after dilation of the eyes. Ethics clearance was obtained and each participant gave informed consent. A descriptive analysis was done.

Results: The median age of the 98 interventionalists screened was 43.5 years. They worked with radiation for a median of 7.5 years. Cataracts occurred in the left eye of 17 (17.3\%) participants and in the right eye of nine (9.2\%). There were five (5.1\%) PSC cataracts in the left eye and one (1\%) in the right eye. The vitreous was abnormal in $19.4 \%$ of participants. The tear break-up time was abnormal in $48 \%$ of participants.

Conclusion: Ionising radiation is an occupational hazard posing a risk to interventionalists' eyes. They are at increased risk of cataracts and dry eye syndrome, which can affect their occupational performance and quality of life. Education can positively influence the radiation safety practices of interventionalists that could reduce the detrimental effects of IR on their eyes.

Keywords: ophthalmological changes; ionising radiation; occupational radiation exposure; radiation cataracts; interventionalists; South Africa.

\section{Introduction}

Ionising radiation (IR) is an occupational health risk for radiation healthcare workers (HCWs). ${ }^{1}$ Doctors who routinely use IR to perform fluoroscopic procedures are at increased risk for the health effects because of IR if they are not properly shielded and protected. ${ }^{1}$ These doctors include interventional radiologists (IRs), interventional adult and paediatric cardiologists (PCs), urologists, orthopaedic surgeons and vascular surgeons.

Radiation-induced injury may be acute where changes are observed immediately post-radiation exposure; consequential effects appear days to weeks later; and late effects emerge months to years after exposure. ${ }^{2}$ Ionising radiation causes damage by several mechanisms. There may be direct damage to deoxyribonucleic acid (DNA) molecules, resulting in cell damage and subsequent cell death. ${ }^{3}$ Water or other molecules may be energised indirectly to form free radicals that then cause cell destruction and necrosis. ${ }^{3}$ Ionising radiation-induced bystander effects (RIBE) occur when the effects of radiation are seen in adjacent nearby cells that were not directly radiated and this results in DNA molecular damage. ${ }^{4}$ The effects of IR may be stochastic or deterministic. $^{5}$ Stochastic effects do not have a threshold limit and include carcinomas, genetic aberrations and cataract formation. ${ }^{5}$ Deterministic effects have a threshold limit and include skin changes. ${ }^{5}$ The eyes are highly radiosensitive organs and every anatomical structure of the eye may be affected if exposed to enough IR. 
The initial changes after high-dose ionising radiation exposure to the lids of the eyes include inflammatory changes, loss of hair around the lids and skin erythema. ${ }^{6}$ Persistent eyelid changes include mal-pigmentation, persistent madarosis and punctal occlusion. ${ }^{6}$ This may be complicated by secondary infection. ${ }^{6}$ The development of telangiectatic vessels is a cause of persistent conjunctival injection, a late feature. ${ }^{6}$ Loss of conjunctival goblet cells may contribute to dry eye syndrome. ${ }^{6}$

Radiation injury indirectly affects the quality of the tear film by damaging structures related to tear production and drainage in the eyelid and conjunctiva. Damaged corneal epithelium also negatively affects the ability of the tear film to adhere to the ocular surface. Ionising radiation can also directly injure the corneal nerve plexus causing reduced corneal sensation. In severe cases this may result in ocular surface keratinisation, corneal degenerative pannus formation and even corneal perforation. ${ }^{6}$

The lens has continual mitotic activity throughout life and an inability to dispose of damaged cells; this makes it highly radiosensitive. In the setting of chronic low-dose exposure to IR, evidence suggests that cataract formation has a stochastic rather than deterministic relationship to radiation exposure. ${ }^{7}$ The cataracts may be cortical, nuclear or posterior sub-capsular (PSC). Ionising radiation-induced cataracts are commonly associated with the PSC region. ${ }^{8}$ In interventionalists, cataracts tend to occur in the left more than right eye, possibly because of where the X-ray beam is positioned during a procedure. ${ }^{7}$

Radiation-induced damage to the vascular beds of the uvea compromises the blood-ocular barrier and thus the immuneprivilege status of the eye. This may results in intraocular inflammation. ${ }^{6}$ Uveitic glaucoma may result, with a potentially devastating visual outcome. ${ }^{6}$ Altered proteins in the sclera may initiate a process ending in scleromalacia. ${ }^{6}$

Radiation retinopathy consequent to high-dose radiation exposure may cause changes similar to diabetic retinopathy. ${ }^{9}$ Radiation damages the vascular endothelium and causes a retinal vasculopathy and includes retinal hard exudates, haemorrhages, microaneuryms, cotton-wool spots and telangiectasia. ${ }^{10}$

Ionising radiation is an occupational hazard that poses a threat to the health of the radiation HCWs. The effects on the eye are varied, and it is thus important that the eye is shielded to protect it from the potentially disabling effects of IR. The poor use of protective eyewear among interventionalists may be because of insufficient understanding of the health risks, but encouraging radiation safety practices may have a positive effect on the eye health of interventionalists. ${ }^{11}$

The aim of this study was to describe the ophthalmological changes in a group of doctors occupationally exposed to IR.

\section{Methods}

This study was nested in a larger study, the methods of which are described in detail elsewhere. ${ }^{12}$ The larger study was a multiple methods study that included eye screening, the completion of a detailed questionnaire and a slit lamp examination. There was also a qualitative component that used interviews and discussion groups to collect data on the perceptions of radiologists on the culture of radiation protection.

\section{Design}

This was a cross-sectional prospective study.

\section{Setting}

Data were collected at seven conferences across South Africa held in the cities of Bloemfontein, Cape Town, Stellenbosch and Johannesburg. The conferences were dedicated radiology and cardiology conferences.

\section{Population}

Interventionalists were defined as doctors who use IR to perform fluoroscopic procedures. We included 98 of the following interventionalists: 25 IRs, 42 adult cardiologists (ACs) and 31 PCs. Our cohort represented 50\% (25/50) of IRs, $18 \%(42 / 229)$ of ACs and 76\% (31/41) of PCs in South Africa. These statistics were provided by the Radiology and Cardiology Societies of South Africa (February 2016). There was no randomisation, and all eligible participants willing to participate were included in the study.

\section{Data collection tools}

The survey was a detailed questionnaire that collected data on demographics, risk factors for cataracts, recreational exposure to radiation, work history of fluoroscopic procedures performed, occupational radiational safety practices and training in radiation safety. We used a standard eye examination clinical check sheet to standardise the eye examination.

\section{Data collection}

The survey was sent to participants prior to the conference and they were invited to complete it electronically. Participants who had not completed it prior to the conference were invited to complete a paper-based version at the conference. Participants were invited to have an ophthalmological examination. Visual acuity was measured with a Snellen chart. Their eyes were dilated and examined with a slit lamp (Haag-Streit BM 900 Slit Lamp, Switzerland). The eye findings were linked to the survey data. Data were collected from June 2015 to September 2017.

\section{Analysis}

A descriptive analysis was performed using STATA $15^{\circledR}$. Averages were estimated for parametric data. Medians and 
interquartile ranges (IQRs) were calculated for nonparametric data. Frequencies were computed for categorical data.

\section{Limitations and strengths of the study}

This was a cross-sectional study and causality for the findings cannot be attributed to occupational radiation exposure. This was a convenient sample and participants may have opted into the study because they had already undergone an ophthalmological examination and knew what to expect, and we thus may have underestimated the burden of ophthalmological findings. Risk factors were self-reported and not verified. There may have been recall error when participants completed the survey. A strength of this study is that all participants were examined by the same ophthalmologists using the same slit lamp and this reduced measurement error.

\section{Ethical considerations}

All participants voluntarily participated in the study and gave informed consent for the survey and the ophthalmological screening. Participants were free to withdraw from any part of the study at any time.

Ethical approval was provided by the Health Sciences Research Ethics Committee of the University of the Free State (ECUFS 44/2015).

\section{Results}

We screened 121 interventionalists and excluded 23 (19.0\%). The reason for excluding these 23 participants was because they had not completed the survey and we could not link their eye screening examination to the survey data. Table 1 describes the demographic details of 98 interventionalists who had their eyes screened and completed the survey. The data in Table 1

TABLE 1: Demographic details of 98 interventionalists.

\begin{tabular}{|c|c|c|c|c|}
\hline Co-variate & Radiologist & $\begin{array}{c}\text { Adult } \\
\text { cardiologist }\end{array}$ & $\begin{array}{l}\text { Paediatric } \\
\text { cardiologist }\end{array}$ & $\begin{array}{c}\text { Total } \\
\text { interventionalists }\end{array}$ \\
\hline \multicolumn{5}{|l|}{ Number } \\
\hline$n$ & 25 & 42 & 31 & 98 \\
\hline$\%$ & 25.5 & 42.9 & 31.6 & 100.0 \\
\hline \multicolumn{5}{|l|}{ Age } \\
\hline Median & 43 & 47.5 & 41 & 43.5 \\
\hline IQR & $39-49$ & $39-57$ & $37-52$ & $38-52$ \\
\hline Minimum & 30 & 31 & 32 & 30 \\
\hline Maximum & 60 & 69 & 69 & 69 \\
\hline \multicolumn{5}{|l|}{ Sex } \\
\hline \multicolumn{5}{|l|}{ Male } \\
\hline$n$ & 13 & 37 & 18 & 68 \\
\hline$\%$ & 52.0 & 88.1 & 58.1 & 69.4 \\
\hline \multicolumn{5}{|l|}{ Female } \\
\hline$n$ & 12 & 4 & 13 & 30 \\
\hline$\%$ & 48.0 & 11.9 & 42.9 & 30.6 \\
\hline \multicolumn{5}{|c|}{ Years worked with ionising radiation } \\
\hline Median & 5 & 9 & 7 & 7.5 \\
\hline IQR & $<1-15$ & $3-20$ & $1-13$ & $3-15$ \\
\hline Minimum & $<1$ & $<1$ & $<1$ & $<1$ \\
\hline Maximum & 32 & 40 & 27 & 40 \\
\hline
\end{tabular}

$I Q R$, interquartile range. are disaggregated for the IRs, the ACs and the PCs. The median age (43.5 years) of interventionalists included in the study was young. A total of $69.4 \%$ of the interventionalists were male.

In Table 2, the self-reported risk factors and co-morbid diseases associated with cataracts for the interventionalists who completed the survey and eye examination are reported. There may have been multiple responses. The risk factors were self-reported and this limits their interpretation. The weight and height used to calculate body mass index (BMI) were self-reported. There were no risk factors in any of the groups that were greater than is expected for the general population. Myopia was slightly higher in the PSC.

TABLE 2: Self-reported risk factors and co-morbid diseases in 98 interventionalists.

\begin{tabular}{|c|c|c|c|c|}
\hline Co-variate & Radiologist & $\begin{array}{c}\text { Adult } \\
\text { cardiologist }\end{array}$ & $\begin{array}{l}\text { Paediatric } \\
\text { cardiologist }\end{array}$ & $\begin{array}{c}\text { Total } \\
\text { interventionalists }\end{array}$ \\
\hline \multicolumn{5}{|l|}{ Number smokers } \\
\hline$n$ & 3 & 2 & 2 & 7 \\
\hline$\%$ & 12.0 & 4.8 & 6.5 & 7.1 \\
\hline Median years smoked & 25 & 12.5 & 18 & 15 \\
\hline IQR (years) & $10-25$ & $10-15$ & $15-21$ & $10-25$ \\
\hline $\begin{array}{l}\text { Median number } \\
\text { cigarettes per day }\end{array}$ & 12 & 6 & 5 & 8 \\
\hline IQR (per day) & $4-15$ & $2-10$ & $2-8$ & $2-12$ \\
\hline \multicolumn{5}{|l|}{ Consumes alcohol } \\
\hline$n$ & 9 & 33 & 18 & 60 \\
\hline$\%$ & 36.0 & 78.6 & 58.1 & 61.2 \\
\hline Median years & 20 & 25 & 20 & 20 \\
\hline IQR & $15-25$ & $18-30$ & $11-30$ & $15-30$ \\
\hline Units per day & 2 & 2 & 2 & 2 \\
\hline IQR & $1-2$ & $1-3$ & $1-2$ & $2-3$ \\
\hline Steroids & 0 & 0 & 0 & 0 \\
\hline \multicolumn{5}{|l|}{ Diabetes } \\
\hline$n$ & 1 & 1 & 0 & 2 \\
\hline$\%$ & 4.00 & 2.40 & 0.00 & 2.04 \\
\hline \multicolumn{5}{|c|}{ Self-reported hypertension } \\
\hline$n$ & 2 & 1 & 0 & 3 \\
\hline$\%$ & 8.0 & 2.4 & 0.0 & 3.1 \\
\hline \multicolumn{5}{|l|}{ BMI } \\
\hline Median & 23.9 & 25.8 & 25.4 & 25.1 \\
\hline IQR & $21.2-27.2$ & $23.3-29.0$ & $24.4-26.6$ & $19.4-31.7$ \\
\hline \multicolumn{5}{|l|}{ Myopia } \\
\hline$n$ & 4 & 6 & 7 & 17 \\
\hline$\%$ & 16.0 & 14.3 & 22.6 & 17.4 \\
\hline \multicolumn{5}{|l|}{ Glaucoma } \\
\hline$n$ & 0 & 1 & 0 & 1 \\
\hline$\%$ & 0.0 & 2.4 & 0.0 & 1.0 \\
\hline \multicolumn{5}{|l|}{ Uveitis } \\
\hline$n$ & 1 & 0 & 0 & 1 \\
\hline$\%$ & 4.0 & 0.0 & 0.0 & 1.0 \\
\hline \multicolumn{5}{|l|}{ Trauma } \\
\hline$n$ & 0 & 0 & 2 & 2 \\
\hline$\%$ & 0.0 & 0.0 & 6.5 & 2.04 \\
\hline \multicolumn{5}{|l|}{ Previous eye symptoms } \\
\hline$n$ & 2 & 2 & 2 & 6 \\
\hline$\%$ & 8.0 & 4.8 & 6.5 & 6.1 \\
\hline \multicolumn{5}{|l|}{ Total } \\
\hline$N$ & 25 & 42 & 31 & 98 \\
\hline$\%$ & 25.5 & 42.9 & 31.6 & 100.0 \\
\hline
\end{tabular}

Note: Multiple responses for all questions possible.

$\mathrm{IQR}$, interquartile range; $\mathrm{BMI}$, body mass index. 
TABLE 3: Ophthalmological findings in the 98 interventionalists.

\begin{tabular}{|c|c|c|c|c|}
\hline \multirow[t]{2}{*}{ Co-variate } & \multicolumn{2}{|c|}{ Right eye } & \multicolumn{2}{|c|}{ Left eye } \\
\hline & $n$ & $\%$ & $n$ & $\%$ \\
\hline \multicolumn{5}{|l|}{ Visual acuity } \\
\hline Normal vision ( $\geq 0.5$ ) & 91 & 92.9 & 90 & 93.9 \\
\hline Abnormal $(<0.5)$ & 7 & 7.1 & 8 & 8.1 \\
\hline \multicolumn{5}{|l|}{ Lid } \\
\hline Normal & 78 & 79.6 & 78 & 79.6 \\
\hline Meibomian gland dysfunction & 16 & 16.3 & 16 & 16.3 \\
\hline Allergic eye disease & 3 & 3.1 & 3 & 3.1 \\
\hline Anatomical defect & 1 & 1.0 & 1 & 1.0 \\
\hline \multicolumn{5}{|l|}{ Conjunctiva } \\
\hline Normal & 90 & 91.8 & 91 & 92.8 \\
\hline Pingueclae & 3 & 3.1 & 3 & 3.1 \\
\hline Pterygium & 2 & 2.0 & 0 & 0.0 \\
\hline Reactive conjunctiva & 2 & 2.0 & 3 & 3.1 \\
\hline Other & 1 & 1.1 & 1 & 1.0 \\
\hline \multicolumn{5}{|l|}{ Iris } \\
\hline Brown & 73 & 74.5 & 73 & 74.5 \\
\hline Blue & 19 & 19.4 & 18 & 18.4 \\
\hline Green & 6 & 6.1 & 7 & 7.1 \\
\hline \multicolumn{5}{|l|}{ Lens (cataract) $\dagger$} \\
\hline PSC & 1 & 1.0 & 5 & 5.1 \\
\hline Cortical & 8 & 8.2 & 12 & 12.2 \\
\hline Nuclear & 21 & 21.4 & 18 & 18.4 \\
\hline \multicolumn{5}{|l|}{ Vitreous } \\
\hline Normal & 79 & 80.6 & 79 & 80.6 \\
\hline Signs of syneresis & 16 & 16.3 & 16 & 16.3 \\
\hline Posterior vitreous detachment & 3 & 3.1 & 2 & 2.0 \\
\hline Degeneration & 0 & 0.0 & 1 & 1.0 \\
\hline \multicolumn{5}{|l|}{ Ocular nerve } \\
\hline Normal & 83 & 84.7 & 83 & 84.7 \\
\hline Features of myopia & 9 & 9.2 & 9 & 9.2 \\
\hline Crowded disc & 6 & 6.1 & 6 & 6.1 \\
\hline \multicolumn{5}{|l|}{ Fundus } \\
\hline Normal & 97 & 98.9 & 98 & 100 \\
\hline Abnormal & 1 & 1.1 & 0 & 0.0 \\
\hline \multicolumn{5}{|l|}{ Tear break-up time } \\
\hline Normal (> $10 \mathrm{~s}$ ) & 49 & 52.1 & 52 & 55.3 \\
\hline Reduced ( $\leq 10 \mathrm{~s}$ ) & 37 & 39.4 & 34 & 36.2 \\
\hline Severe $(<6 s)$ & 8 & 8.5 & 8 & 8.5 \\
\hline
\end{tabular}

Note: A participant may have had more than one finding. Data set in bold are for for data that is higher than expected.

PSC, posterior sub-capsular.

$\dagger$, not controlled for age.

In Table 3, the ophthalmological findings in the 98 interventionalists are reported. A participant may have had more than one finding. The majority of participants had normal vision and brown eyes. There were no pathologies observed in the iris. The prevalence of cortical and PSC cataracts together was $18.8 \%$. The vitreous was abnormal in $19.3 \%$ of participants. The optic nerve was abnormal in $15.3 \%$ of participants. The tear break-up time (TBUT) was reduced in approximately $48 \%$ of participants, suggestive of dry eye disease (DED).

\section{Discussion}

Interventionalists are at increased risk of developing radiation-induced cataracts. ${ }^{7}$ Radiation-induced cataracts are commonly described to occur in the PSC. ${ }^{1}$ In a French study (2009-2011), the prevalence of PSC cataracts was estimated at
$17 \%$ ( $N=109$; confidence interval [CI]: $10 \%-24 \%$; odds ratio of 3.8 [1.3-11.4]). ${ }^{13}$ In a Malaysian study conducted in 2009, the prevalence of PSC cataracts was reported as $54 \%(N=56$; CI: 35-73; relative risk of 5.7 [CI: $1.5-22]){ }^{14}$ The prevalence of PSC cataracts in our cohort was lower than reported in these studies. ${ }^{13,14}$ This may be because of a lower median age and lower median number of years exposed to occupational IR. The findings are, however, clinically significant as they suggest that even at a lower median age and years of IR exposure, participants are at risk of developing cataracts early, which may be occupationally related. Cataracts associated with occupational exposure to IR are typically described to occur more commonly in the left eye and in the PSC region, but recent evidence suggests that cortical cataracts may also be associated with IR exposure. ${ }^{15,16}$ The postulated reason that the cataracts occur more commonly in the left eye is because the radiation beam is positioned closest to the left eye when procedures are performed. The prevalence of cataracts (cortical and PSC) was 17.3\% (17/98) in the left eye and $9.2 \%$ (9/98) in the right eye, which further adds weight to our argument that the presence of these cataracts is of clinical significance.

The Tear Film and Ocular Surface Society (TFOS) defines DED as a multifactorial disease of the ocular surface because of the loss of homeostasis of the tear film with accompanying eye symptoms. ${ }^{17}$ The prevalence varies between $5 \%$ and $50 \%$ and between regions. ${ }^{17}$ In an Australian study, the prevalence of DED varied between $5.5 \%$ and $16.3 \%$ depending on the test used to make the diagnosis. ${ }^{18}$ In a Japanese study, the prevalence was higher in women $(21.6 \%)$ than men $(12.5 \%) .{ }^{19}$ Lacrimal damage-resulting DED is described in patients who received whole brain radiation therapy. ${ }^{20}$ In a study by Bhandare et al., 40 of 78 (51\%) patients treated with external beam radiation developed DED. ${ }^{21}$ There is a paucity of data on the effects of low-dose IR exposure in the catherisation laboratory and parallels are drawn from IR exposure in other settings.

The diagnosis of DED is made on the basis of symptomatology and one or more homeostatic marker results. ${ }^{17}$ A clinical diagnosis of DED was not made in this study, but we did corroborate our findings by asking participants to report on their symptomatology. The TBUT was measured and is used as a proxy, suggestive of DED. We used a cut-off of $\leq 10 \mathrm{~s}$ to indicate a reduced TBUT with moderate impairment and $\leq 6 \mathrm{~s}$ for severely reduced TBUT. ${ }^{22}$ Dry eye disease is a debilitating socio-medical condition that affects the quality of life of those affected. ${ }^{23}$ This has serious implications for the quality of life of interventionalists as the TBUT was approximately $48 \%$ and may be related to occupational IR exposure.

Cataracts, dry eye syndrome and other ophthalmological changes that may be related to occupational IR exposure are not life-threatening and are generally surgically or medically treatable and even curable, but they may 
detrimentally affect quality of life and occupational performance. $^{23}$ They have public health and economic implications as they may affect work performance and they are costly to treat. ${ }^{17}$ This necessitates implementing measures to prevent these disease outcomes.

There is a need to improve the awareness of the health risk to the eye among interventionalists so as to reduce the complications associated with occupational IR exposure. ${ }^{11}$ General practitioners, ophthalmologists and occupational health physicians should also be vigilant in considering this risk as part of routine screening and examination of interventionalists.

The implementation of these preventative measures requires developing and sustaining a culture of radiation protection. ${ }^{24}$ This can be achieved by formally including radiation physics and radiobiology in the training curriculum of interventionalists. A South African study showed that there was a gap in the training on radiation safety in South African cardiologists. ${ }^{25}$ Radiation safety training, however, also needs to be ongoing for it to be effective. ${ }^{26}$ Adequate education on radiation safety mitigates the occupational risk of IR exposure to interventionalists working in the catheterisation laboratory. ${ }^{1}$

\section{Conclusion}

Interventionalists are at an increased risk of developing ophthalmological complications because of occupational exposure to IR. They are at an increased risk of developing cataracts in the PSC region and DED. They need to be screened regularly for these ophthalmological changes. Mitigating factors should be implemented and enforced to protect them from this occupational hazard. Formalising radiation safety training in their training curriculum is a necessary mitigating preventative strategy.

\section{Acknowledgements}

The authors thank Margaret Ann Sweetlove who assisted with data collection during the project, 'Radiation induced lens changes and development of a radiation safety framework for interventionalists', submitted to the University of the Free State. (available at http:/ / scholar.ufs. ac.za:8080/handle/11660/9718)

\section{Competing interests}

The authors have declared that no competing interests exist.

\section{Authors' contributions}

W.I.D.R., A.R., L.N. and W.M. conceptualised the study. A.R. and L.N. collected the data for the study. W.I.D.R., A.R., W.M. and L.N. analysed and interpreted the data. A.R. and L.N. wrote the first draft of this article. All authors gave input to the article. All authors read and approved the final article.

\section{Funding information}

The PhD thesis from which this study emanated was funded by the Medical Research Council of South Africa under the South African Medical Research Council (SAMRC) Clinician Researcher Programme. A.R. received the Discovery Foundation Scholarship, which funded the data collection of this project. The South African Heart Association (Free State Branch) partially funded the data collection of this project. W.I.D.R. is the recipient of an National Research Fund (NRF) incentive grant.

\section{Data availability statement}

Data sharing is not applicable to this article.

\section{Disclaimer}

All authors declare that the views expressed in this article are their own and not the institutions they represent.

\section{References}

1. Smilowitz NR, Balter S, Weisz G. Occupational hazards of interventional cardiology. Cardiovasc Revasc Med. 2013;14:223-228. https://doi.org/10.1016/j.carrev.2013. 05.002

2. Stone $\mathrm{HB}$, Coleman $\mathrm{CN}$, Anscher MS, Mcbride WH. Effects of radiation on normal tissue: Consequences and mechanisms. Lancet Oncol. 2003;4(4):529-536.

3. Sowa M, Arthurs BJ, Estes BJ, Morgan WF. Effects of ionizing radiation on cellular structures, induced instability and carcinogenesis. EXS. 2006;96:293-301.

4. Desouky O, Ding N, Zhou G. Targeted and non-targeted effects of ionizing radiation. J Radiat Res Appl Sci. 2015;8(2):247-254. https://doi.org/10.1016/j. jrras.2015.03.003

5. Brown KR, Rzucidlo E. Acute and chronic radiation injury. J Vasc Surg 2011;53(1):15S-21S. https://doi.org/10.1016/j.jvs.2010.06.175

6. Donnenfeld E, Ingraham H, Abramson D. Medical radiology (diagnostic imaging and radiation oncology). In: Alberti W, Sagerman R, editors. Radiotherapy of intraocular and orbital tumors. Berlin: Springer, 1993; pp. 261-270.

7. Kleiman NJ. Radiation cataract. Ann ICRP. 2012;41(3-4):80-97. https://doi.org/ 10.1016/j.icrp.2012.06.018

8. Little MP. A review of non-cancer effects, especially circulatory and ocular diseases. Radiat Environ Biophys. 2013;52(4):435-449. https://doi.org/10.1007/ s00411-013-0484-7

9. Zamber R, Kinyoun J. Radiation retinopathy. West J Med. 1992;157:530-533.

10. Brown G, Shields J, Sanborn G, Augsburger J, Savino P, Schatz N. Radiation retinopathy. Ophthalmology. 1982;89(12):1494-1501. https://doi.org/10.1016/ s0161-6420(82)34611-4

11. Seals KF, Lee EW, Cagnon CH, Al-Hakim RA, Kee ST. Radiation-induced cataractogenesis: A critical literature review for the interventional radiologist. Cardiovasc Interv Radiol. 2016;39(2):151-160. https://doi.org/10.1007/s00270015-1207-z

12. Rose A, Rae W, Chikobvu P, Marais W. A multiple methods approach: Radiation associated cataracts and occupational radiation safety practices in interventionalists in South Africa. J Radiol Prot. 2017;37(2):329-339. https://doi.org/10.1088/1361 6498/aa5eee

13. Jacob S, Boveda S, Bar O, et al. Interventional cardiologists and risk of radiationinduced cataract: Results of a French multicenter observational study. Int J Cardio. 2013;167(5):1843-1847. https://doi.org/10.1016/j.ijcard.2012.04.124

14. Ciraj-Bjelac O, Rehani MM, Sim KH, Liew HB, Vano E, Kleiman NJ. Risk for radiationinduced cataract for staff in interventional cardiology: Is there reason for concern? Catheter Cardiovasc Interv. 2010;76(6):826-834. https://doi.org/10.1002/ccd. 22670

15. Stahl CM, Meisinger QC, Andre MP, Kinney TB, Newton IG. Radiation risk to the fluoroscopy operator and staff. Am J Roentgenol. 2016;207(4):737-744. https:// doi.org/10.2214/AJR.16.16555

16. Hammer GP, Scheidemann-Wesp U, Samkange-Zeeb F, Wicke H, Neriishi K, Blettner M. Occupational exposure to low doses of ionizing radiation and cataract development: A systematic literature review and perspectives on future studies. Radiat Env Biophys. 2013;52(3):303-319. https://doi.org/10.1007/s00411-0130477-6

17. Craig JP, Nelson JD, Azar DT, et al. TFOS DEWS II report executive summary. Ocular Surf. 2017;15(4):1-11. https://doi.org/10.1016/j.jtos.2017.08.003

18. McCarty CA, Stanislausky YL, Bansal AK, Livingston PM, Taylor HR. The epidemiology of dry eye in Melbourne, Australia. Opthalmology. 1998;105(6):1114-1119. https:// doi.org/10.1016/S0161-6420(98)96016-X 
19. Uchino M, Nishiwaki Y, Michikawa T, et al. Prevalence and risk factors of dry eye disease in Japan: Koumi Study. Ophthalmology. 2011;118(12):2361-2367. https:// disease in Japan: Koumi Study. Ophthalmo

20. Jeganathan VSE, Wirth A, MacManus MP. Ocular risks from orbital and periorbital radiation therapy: A critical review. Int J Radiat Oncol Biol Phys. 2011;79(3):650-659. https://doi.org/10.1016/j.ijrobp.2010.09.056

21. Bhandare N, Moiseenko V, Song WY, et al. Severe dry eye syndrome after radiotherapy for head-and-neck tumors. Int J Radiat Oncol Biol Phys. 2012;82(4):1501-1508. https://doi.org/10.1016/j.ijrobp.2011.05.026

22. Amada MAY, Inoshita SHK. New perspectives on dry eye definition and diagnosis: A consensus report by the Asia Dry Eye Society. Ocular Surf. 2017;15(1):65-76. https://doi.org/10.1016/j.jtos.2016.09.003
23. Uchino M, Schaumberg DA. Dry eye disease: Impact on quality of life and vision Curr Ophthalmology Rep. 2014;1(2):51-57. https://doi.org/10.1007/s40135013-0009-1

24. Rose A, Uebel KE, Rae WID. Interventionalists' perceptions on a culture of radiation protection. S Afr J Rad. 2018;22(1):a1285. https://doi.org/10.4102/sajr. v22i1.1285

25. Rose $A$, Rae W. Perceptions of radiation safety training among interventionalists in South Africa. Cardiovasc J Afr. 2017;28(3):1-5. https://doi.org/10.5830/CVJA-2017-028

26. Georges J-L, Livarek B, Gibault-Genty G, et al. Reduction of radiation delivered to patients undergoing invasive coronary procedures. Effect of a programme for dose reduction based on radiation-protection training. Arch Cardiovasc Dis. 2009;102(12):821-827. https://doi.org/10.1016/j.acvd.2009.09.007 